Document downloaded from:

http://hdl.handle.net/10251/99043

This paper must be cited as:

Gonzalez-Camejo, J.; Barat, R.; Paches Giner, MAV.; Murgui Mezquita, M.; Seco Torrecillas, A.; Ferrer, J. (2018). Wastewater nutrient removal in a mixed microalgae bacteria culture: effect of light and temperature on the microalgae bacteria competition. Environmental Technology. 39(4):503-515. doi:10.1080/09593330.2017.1305001

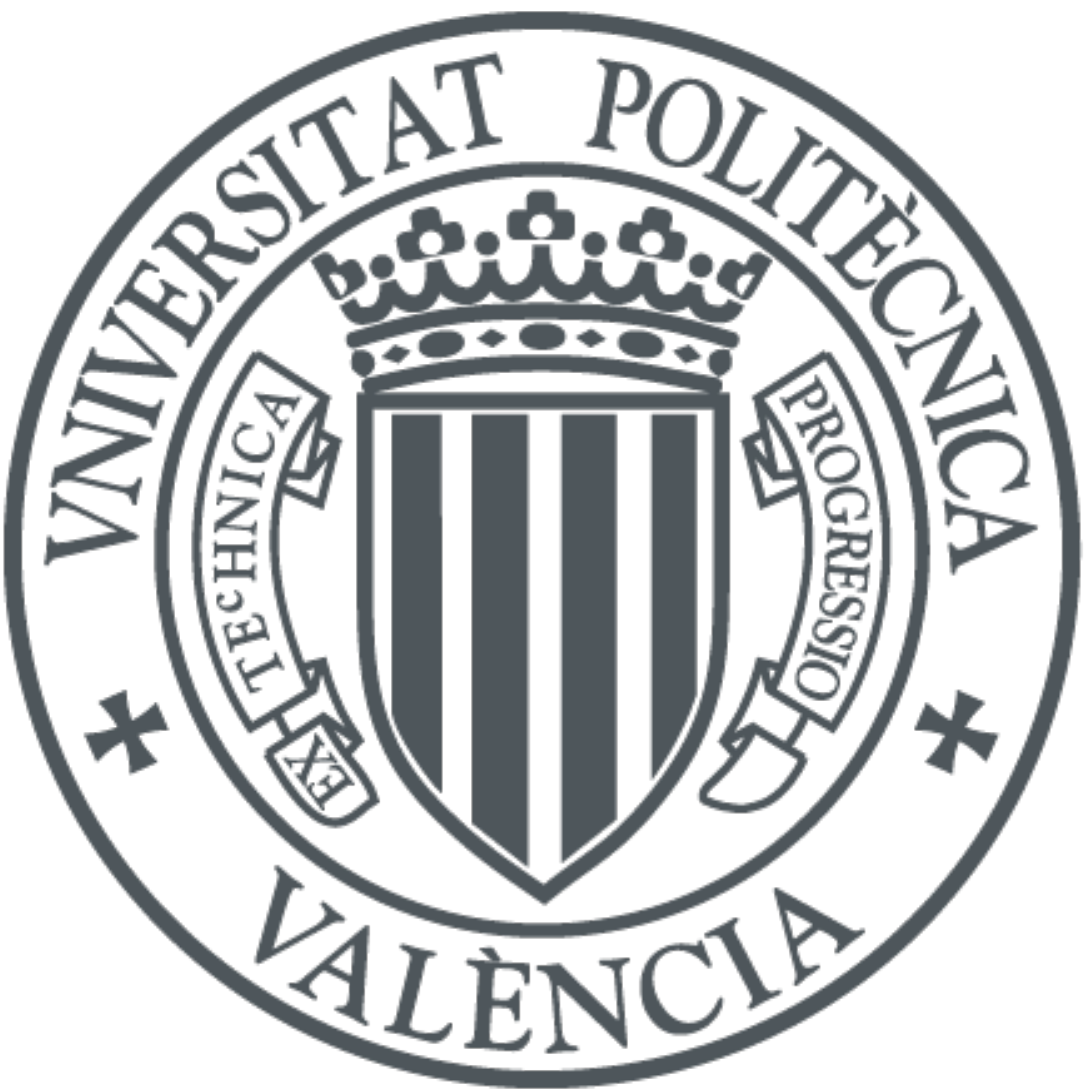

The final publication is available at

https://doi.org/10.1080/09593330.2017.1305001

Copyright Taylor \& Francis

Additional Information 


\title{
Wastewater Nutrient Removal in a Mixed Microalgae-bacteria Culture: Effect of Light and Temperature on the Microalgae-bacteria Competition.
}

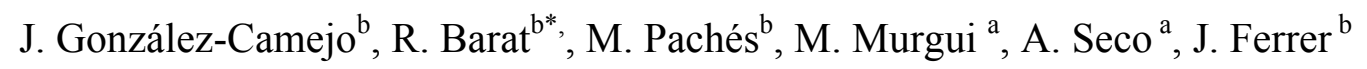

${ }^{a}$ Departamento de Ingeniería Química, Universitat de València, Avinguda de la Universitat, $\quad$ s/n., 46100 Burjassot, Valencia, Spain.E-mail addresses: monica.murgui@uv.es; aurora.seco@uv.es.Tel.: +34 963543 927; fax: +34 963544 898.

${ }^{b}$ Instituto de Ingeniería del Agua y Medio Ambiente, IIAMA, Universitat Politècnica de València, Camí de Vera, s/n., 46022 Valencia, Spain. E-mail addresses: jogonca4@upv.es;rababa@dihma.upv.es;mapacgi@upvnet.upv.es;jferrer@hma.upv.es. Tel.: +34963877007.

* Corresponding author

\begin{abstract}
The aim of this study was to evaluate the effect of light intensity and temperature on nutrient removal and biomass productivity in a microalgae-bacteria culture and their effects on the microalgae-bacteria competition. Three experiments were carried out at constant temperature and various light intensities: 40,85 and $125 \mu \mathrm{E} \cdot \mathrm{m}^{-2} \cdot \mathrm{s}^{-1}$. Other two experiments were carried out at variable temperatures: $23 \pm 2$ and $28 \pm 2{ }^{\circ} \mathrm{C}$ at light intensity of 85 and $125 \mu \mathrm{E} \cdot \mathrm{m}^{-2} \cdot \mathrm{s}^{-1}$, respectively. The photobioreactor was fed by the effluent from an anaerobic membrane bioreactor. High nitrogen and phosphorus removal efficiencies (about 99\%) were achieved under the following operating
\end{abstract}


conditions: $85-125 \mu \mathrm{E} \cdot \mathrm{m}^{-2} \cdot \mathrm{s}^{-1}$ and $22 \pm 1{ }^{\circ} \mathrm{C}$. In the microalgae-bacteria culture studied, increasing light intensity favoured microalgae growth and limited the nitrification process. However, a non-graduated temperature increase (up to $32^{\circ} \mathrm{C}$ ) under the light intensities studied caused the proliferation of nitrifying bacteria and the nitrite and nitrate accumulation. Hence, light intensity and temperature are key parameters in the control of the microalgae-bacteria competition.

Biomass productivity significantly increased with light intensity, reaching $50.5 \pm 9.6$, $80.3 \pm 6.5$ and $94.3 \pm 7.9 \mathrm{mgVSS} \cdot \mathrm{L}^{-1} \cdot \mathrm{d}^{-1}$ for a light intensity of 40,85 and $125 \mu \mathrm{E} \cdot \mathrm{m}^{-}$ ${ }^{2} \cdot \mathrm{s}^{-1}$, respectively.

\section{Keywords}

Bacteria competition; Light; Microalgae; Nutrient removal; Wastewater.

\section{Introduction}

In recent decades wastewater treatment plants (WWTPs) are evolving to more efficient technology in order to reduce the total carbon footprint of the process. In this regard, anaerobic treatments have several advantages compared to aerobic processes: no aeration is needed, slow sludge production because of the low biomass yield of anaerobic organisms [1] and biogas production, which improves the energetic balance $[2]$.

Anaerobic Membrane Bioreactors (AnMBR) technology appears as a useful application for anaerobic wastewater treatment [3], since it allows decoupling hydraulic retention time (HRT) and biomass retention time (BRT). The AnMBR system achieves a high quality effluent in terms of total suspended solids (TSS) and chemical oxygen demand 
(COD) [2]. Nevertheless, this system is not able to efficiently remove inorganic nutrients (mainly nitrogen and phosphorus) which cannot be directly discharged into the aquatic environment as they could cause serious eutrophication problems, affecting water quality. In fact, the European Union Council Directive 91/271/EEC [4] indicates that the discharge limits of nitrogen and phosphorus for a WWTP $(>100,000$ p.e.) are $10 \mathrm{mgN} \cdot \mathrm{L}^{-1}$ and $1 \mathrm{mgP} \cdot \mathrm{L}^{-1}$, respectively, considerably lower than the typical values obtained for these nutrients in the effluent of an AnMBR process [5].

Microalgae offer a win-win alternative for tertiary wastewater treatment due to their ability to simultaneously remove inorganic nitrogen and phosphorus to meet the effluent standards and at the same time produce valuable biomass which may be used to produce biofuels [6, 7], biogas [8] and other valuable products [6,9]. In addition, as photosynthetic organisms, they are able to absorb carbon dioxide, thus contributing to reducing greenhouse gas emissions. It is remarkable that microalgae have been already presented as a potential technology able to reduce the nutrient concentration in the effluent from an AnMBR [5].

Nevertheless, in mixed microalgae cultures, the other microorganisms compete with algae for nutrients. For instance, the coexistence of microalgae and nitrifying bacteria (both ammonia-oxidizing bacteria (AOB) and nitrite-oxidizing bacteria (NOB)) has been already reported in the treatment of wastewater [10]. AOB transform ammonium into nitrite, while NOB carry out the second nitrification step by oxidizing nitrite into nitrate. The nitrification process therefore implies two negative effects in the use of microalgae for wastewater treatment: (i) the reduction of ammonium by AOB does not involve a net nitrogen reduction as it is oxidized to nitrate, which is not as easily assimilated by microalgae as ammonium [11]; (ii) the limitation of microalgae growth 
when the concentration of ammonium in the culture is low. In fact, Meseck et al. [12] concluded that the presence of nitrifying bacteria in a microalgae culture of Tetraselmis chui reduced the specific growth rate due to their competition for nutrients. However, Risgaard-Petersen et al. [13] observed that microalgae became the predominant group under non-limiting ammonium due to their higher growth rate. Thus, if maximum biomass productivity of microalgae is desired, the optimal conditions for microalgae growth must be applied for them to dominate the competition.

Two key factors that affect the microalgae activity are light and temperature [14].

Microalgae growth is a direct function of the light intensity supplied as long as it remains under the optimum light intensity. Over this value, the photosystem II reactor centres of the microalgae can be damaged, which implies a reduction of the carbon needed to carry out the photosynthesis process, causing photoinhibition [15]. On the other hand, if the supplied light intensity is low, the availability of light is restricted to the surface area of the photobioreactor [16], therefore photolimitation occurs.

Temperature is another parameter which must be taken into account in microalgal growth. Many species of microalgae are able to grow in a wide range of temperature, but all of them show an optimum value in which they are inhibited if they pass it [17], and may even lead to cell death [18]. In fact, Martínez et al. [19] observed a considerable reduction in the specific growth rate and biomass productivity of Scenedesmus obliquus when the temperature was over $30^{\circ} \mathrm{C}$. Li et al. [20] reported that Scenedesmus sp. LX1 could grow within a wide temperature range: $10-30^{\circ} \mathrm{C}$; reaching the maximum specific growth rate at $25^{\circ} \mathrm{C}$.

It must be highlighted that most of previous studies have been focused on the effect of light intensity and temperature over pure cultures and many of them have used an 
artificial medium as nutrients source, but scarce studies have shown the effect of key parameters of microalgae growth, such as light and temperature, over the microalgaebacteria competition for nutrients in real wastewater.

The aim of the present study is to analyse the effect of light intensity and temperature on nutrient removal and biomass productivity in an indigenous microalgae-bacteria culture dominated by Scenedemus spp. and their effect over the competition microalgaebacteria. The system was fed by nutrient-loaded (ammonium and phosphate) effluent from an AnMBR which treated urban wastewater.

\section{Material and Methods}

\subsection{Influent wastewater composition}

The effluent of an anaerobic membrane bioreactor pilot plant was used as microalgae PBR influent. Further details of the characteristics of the AnMBR may be found in [2, 21].

The AnMBR effluent was collected every day and taken to the laboratory to feed the lab-scale photobioreactor (PBR). The main characteristics of the AnMBR effluent during the whole experimental period were: ammonium of $57.4 \pm 2.2 \mathrm{mgN}-\mathrm{NH}_{4} \cdot \mathrm{L}^{-1}$, phosphate of $7.0 \pm 0.9 \mathrm{mgP}-\mathrm{PO}_{4} \cdot \mathrm{L}^{-1}, \mathrm{~N}: \mathrm{P}$ molar ratio of $17.6 \pm 1.4 \mathrm{molN} \cdot \mathrm{molP}^{-1}$, total COD of $51 \pm 8 \mathrm{mgCOD} \cdot \mathrm{L}^{-1}$, alkalinity of $737 \pm 38 \mathrm{mgCaCO} 3 \cdot \mathrm{L}^{-1}$, volatile fatty acids of $1.5 \pm 0.5 \mathrm{mgHAc} \cdot \mathrm{L}^{-1}$, and sulphide of $100.3 \pm 12.4 \mathrm{mgS} \cdot \mathrm{L}^{-1}$. Nitrite and nitrate were negligible in the AnMBR effluent.

It is relevant that the $\mathrm{N}: \mathrm{P}$ molar ratio in the effluent during this time remained at similar values to the one reported by Rawat et al. [7] and Reynolds [22]: 16. Hence, the 
AnMBR effluent allowed microalgae to remove nitrogen and phosphorus efficiently and simultaneously.

Regarding organic matter loading, soluble COD in this AnMBR effluent is inert, thus it enhanced photoautotrophic metabolism typical of microalgae and limited heterotrophic activity. Due to the high sulfide concentration, the AnMBR effluent was previously aerated to oxidize the sulphide to sulphate since sulphide acts as a specific inhibitor of microalgae [23].

\subsection{Inoculum and pre-culture conditions}

The microalgae used as inoculum in the present study were isolated from the walls of the secondary clarifier in the Carraixet WWTP (Alboraya, Spain), which consisted of a complex ecosystem containing microalgae, algae and bacteria (including Cyanobacteria). Prior to the inoculation of the lab-scale PBR, the sample from the secondary clarifier was passed through a laboratory paper filter to remove filamentous bacteria and zooplankton from the reactor. The culture was adapted to the growth medium with continuous illumination $\left(85 \mu \mathrm{E} \cdot \mathrm{m}^{-2} \cdot \mathrm{s}^{-1}\right)$. The medium consisted of a nutrient-loaded effluent from the aforementioned AnMBR pilot plant (see Section 2.1). Temperature and $\mathrm{pH}$ were maintained at $22 \pm 1^{\circ} \mathrm{C}$ and $7.4 \pm 0.3$, respectively. Ten days later, under the cited cultivation conditions, microalgae reached a concentration of 447 $\operatorname{mgVSS} \cdot \mathrm{L}^{-1}$, which was considered appropriate for the PBR to be fed in semicontinuous mode (see Section 2.3). Scenedesmus spp. became the main microalgae genus present in the PBR. Scenedesmus have been consistently reported as an adaptable microalgae genus able to grow in several types of wastewater [24, 25]. 


\subsection{Photobioreactor: description, control and operation}

The PBR consisted of a cylindrical transparent tank $(20 \mathrm{~cm}$ internal diameter $)$ with a working volume of $8 \mathrm{~L}$ (see Figure 1a). To achieve suitable culture homogenisation and avoid biofilms on the walls, the culture was stirred with air at a flow rate of 1.0-1.2 $\mathrm{L} \cdot \mathrm{min}^{-1}$ through four fine bubble diffusers placed crosswise on the bottom. In order to maintain fixed $\mathrm{pH}$ in the $\mathrm{PBR}$, pure $\mathrm{CO}_{2}(99.9 \%)$ was injected into the gas flow from a pressurised cylinder at 1-1.5 bar pressure when the $\mathrm{pH}$ value rose above 7.5. Controlling $\mathrm{pH}$ in the reactor helped to prevent undesirable phenomena such as phosphate precipitation and the ammonia stripping losses. This stripping can be considered negligible when $\mathrm{pH}$ values are under 9.0 and ammonia concentration is under $65 \mathrm{mgN} \cdot \mathrm{L}^{-1}[26]$.

The physical-chemical parameters of the algae culture such as temperature, $\mathrm{pH}$ and dissolved oxygen were monitored online in the PBR and logged in a PC using data acquisition software. For $\mathrm{pH}$, the signal from the corresponding electrodes was processed by a multiparametric analyser (CONSORT C832, Belgium), while temperature and dissolved oxygen were measured by a 4-Star multiparametric analyser (Thermo Scientific) connected to a 087003RDO probe.

The PBR was operated in a semi-continuous mode without biomass retention; therefore BRT and HRT had the same value. The feed was the nutrient-loaded effluent from the AnMBR system used in the pre-culture (see section 2.1). To keep BRT and HRT constant at 8 days, every six hours ( 4 feed cycles a day) a peristaltic pump controlled by a PC fed the PBR by pulse with $0.25 \mathrm{~L}$ of AnMBR effluent. The total volume remained constant since the reactor had an overflow at the top. 


\subsection{Experimental design}

Table 1 shows the operational conditions (light, temperature and dissolved oxygen) in each of the five experiments conducted in the present study. The experimental design was based on two variables: light and temperature. Light was supplied at three different intensities (see Table 1). In these three experiments (L1, L2 and L3), the temperature remained constant. On the other hand, in experiments $\mathrm{T} 1$ and $\mathrm{T} 2$ temperature was not controlled (see Table 1).

As light source, fluorescent lamps (Sylvania Grolux, $18 \mathrm{~W}$ ) were placed vertically around the PBR at a distance of $20 \mathrm{~cm}$ (see Figure 1b). Four lamps were switched on in Exp. L1 (positions: 1, 2, 11 and 12); eight units in Exp. L2 and T1 (positions: 5, 6, 7 and 8), and the whole set of lamps in Exp. L3 and T2. Lighting was provided 24 hours a day. Photosynthetically active radiation (PAR: 400-700 nm) values were measured by a photo sensor (HOBO_Smart Sensor, s-lia-m003).

In these experiments no inhibition of microalgae by ammonium was expected since Park et al. [24] obtained inhibition of Scenedesmus sp. with concentrations of ammonium higher than $200 \mathrm{mg} \mathrm{N} \cdot \mathrm{L}^{-1}$ (the maximum ammonium concentration of the AnMBR effluent was $70.7 \mathrm{mgN} \cdot \mathrm{L}^{-1}$ ). Furthermore, inhibition by high concentration of dissolved oxygen was not expected as it remained under $110 \%$ (see Table 1). Vonshak and Torzillo [27] reported that dissolved oxygen could inhibit microalgae growth when it was higher than $400 \%$.

In order to control the temperature in the PBRs, Exp. L1, L2 and L3 were conducted inside a climatic chamber. As previously indicated, in Exp. T1 and T2 the PBR was not run under controlled temperature. 


\subsection{Sampling and analysis}

\subsubsection{Analytical Methods}

Nutrient removal by microalgae culture was evaluated by recording daily inorganic nitrogen and phosphate levels in the influent (AnMBR effluent) and also in the soluble fraction taken from the PBR. The soluble fraction of the culture was obtained by filtration through $0.45 \mu \mathrm{m}$ pore size glass fibre filters (Millipore). Volatile suspended solids (VSS) and chlorophyll were determined 3 times a week to verify biomass growth and chlorophyll content. VSS was evaluated according to method 2540-E of Standard Methods [28]. Chlorophyll content was determined by the tricromatic method based on visible spectroscopy [28], using Jeffrey and Humphrey equations [29] to obtain the concentration. Pigment extraction was performed with acetone $90 \%$.

Ammonium, nitrite, nitrate and phosphate were determined according to Standard Methods [25]: 4500-NH3-G, 4500-NO2-B, 4500-NO3-H and 4500-P-F, respectively, in a Smartchem 200 automatic analyzer (WestcoScientific Instruments, Westco).

\subsubsection{Calculations}

The performance of the PBR and the microalgae-bacteria competition were evaluated through the nutrient removal efficiencies and biomass productivity. All efficiencies were calculated on a daily balance basis considering influent and effluent terms. All nutrients (soluble nitrogen compounds and phosphate) were assumed to be available for biomass growth (as in the case of microalgae and bacteria). Phosphorus precipitation (e.g. as calcium phosphate or struvite) was negligible due to the low solubility of this species in water at neutrality [30]. Moreover, the oxygen concentration maintained in the PBR due to photosynthetic activity (see Table 1) and the very low level of 
biodegradable carbon made denitrification unlikely. A nitrogen mass balance made on a few runs confirmed both hypotheses (data not shown). It was therefore assumed that was removal of nutrients was only caused by biological processes.

The ammonium removal efficiency (ARE) represents the percentage of ammonium assimilated by both microalgae and nitrifying bacteria (Eq. l). The ammonium removal efficiency by microalgae (mARE) shows the ammonium assimilated by microalgae only. This was calculated as ARE, but deducting the ammonium nitrified as nitrite or nitrate $\left(\mathrm{NO}_{\mathrm{X}}\right)(E q .2)$. The phosphorus removal efficiency (PRE) is the percentage of phosphate assimilated by microalgae. It was calculated similarly to ARE. Since microalgae were the dominant community of the culture, microalgal activity was assumed as solely responsible for $\mathrm{P}$ removal in these experiments.

$$
\begin{gathered}
\operatorname{ARE}(\%)=\frac{I_{N H 4}-E_{N H 4}}{I_{N H 4}}(E q .1) \\
\operatorname{mARE}(\%)=\frac{I_{N H 4}-E_{N H 4}-E_{N O 2}-E_{N O 3}}{I_{N H 4}}(E q .2)
\end{gathered}
$$

The biomass productivity was calculated according to Eq. 3:

$$
B P\left(m g V S S \cdot L^{-1} \cdot d^{-1}\right)=\frac{V S S \cdot V_{p}}{\mathrm{~V}}(E q .3)
$$

Where BP is the biomass productivity of the PBR $\left(\mathrm{mgVSS} \cdot \mathrm{L}^{-1} \cdot \mathrm{d}^{-1}\right)$, VSS is the volatile suspended solids concentration $\left(\mathrm{mgVSS} \cdot \mathrm{L}^{-1}\right), \mathrm{V}_{\mathrm{p}}$ is the daily purged volume from the PBR $\left(\mathrm{L} \cdot \mathrm{d}^{-1}\right)$ and $\mathrm{V}$ is the volume of the PBR $(\mathrm{L})$.

In order to study the performance in the use of light by the microalgae-bacteria culture, the ammonium removal rate:light irradiance ratio and phosphorus removal rate:light irradiance ratio were calculated according to Eq. 4, Eq. 5 and Eq. 6:

$\mathrm{ARR} / \mathrm{I}=\frac{\mathrm{ARR} \cdot \mathrm{V}_{\mathrm{PBR}} \cdot 10^{6}}{\mathrm{I} \cdot \mathrm{S} \cdot 24 \cdot 3600}$ 
$\mathrm{mARR} / \mathrm{I}=\frac{\mathrm{mARR} \cdot \mathrm{V}_{\mathrm{PBR}} \cdot 10^{6}}{\mathrm{I} \cdot \mathrm{S} \cdot 24 \cdot 3600}$

$\mathrm{PRR} / \mathrm{I}=\frac{\mathrm{PRR} \cdot \mathrm{V}_{\mathrm{PBR}} \cdot 10^{6}}{\mathrm{I} \cdot \mathrm{S} \cdot 24 \cdot 3600}$

Where ARR/I is the ammonium removal rate:light irradiance ratio $\left(\mathrm{mgN} \cdot \mathrm{mol}\right.$ photons ${ }^{-}$ ${ }^{1}$ ), $\mathrm{mARR} / \mathrm{I}$ is the ammonium removal rate by microalgae:light irradiance ratio $\left(\mathrm{mgN} \cdot \mathrm{mol}\right.$ photons $\left.^{-1}\right), \mathrm{PRR} / \mathrm{I}$ is the phosphorus removal rate:light irradiance ratio $\left(\mathrm{mgP} \cdot \mathrm{mol}\right.$ photons $\left.{ }^{-1}\right)$, ARR is the ammonium removal rate $\left(\mathrm{mgN} \cdot \mathrm{L}^{-1} \cdot \mathrm{d}^{-1}\right), \mathrm{mARR}$ is the ammonium removal rate by microalgae $\left(\mathrm{mgN} \cdot \mathrm{L}^{-1} \cdot \mathrm{d}^{-1}\right), \mathrm{PRR}$ is the phosphorus removal rate $\left(\mathrm{mgP} \cdot \mathrm{L}^{-1} \cdot \mathrm{d}^{-1}\right), \mathrm{I}$ is the mean light PAR irradiance applied to the PBRs' surface ( $\mu \mathrm{mol}$ photons $\cdot \mathrm{m}^{-2} \cdot \mathrm{s}^{-1}$ ) and $\mathrm{S}$ is the illuminated PBRs surface $\left(\mathrm{m}^{2}\right)$.

\subsubsection{Microbiological Method}

To analyse the microalgae community, $50 \mu \mathrm{L}$ of sample were filtered with $0.2 \mu \mathrm{m}$ membranes (Millipore GTTP) twice a week. The filters were washed with distilled water to eliminate the retained salt and then dehydrated with successive $50 \%, 80 \%, 90 \%$ and $99 \%$ ethanol washes. Cell counts were performed by epifluorescence microscopy on a Leica DM2500, using the 100x-oil immersion lens. A minimum of 300 cells were counted and at least 100 cells of the most abundant species or genera were counted with an error of less than $20 \%$ [31]. All the reported results were obtained from the above analyses conducted in duplicate.

The FISH (Fluorescent In Situ Hybridization) technique was performed once a week to detect just the presence of nitrifiers, both ammonia and nitrite-oxidizing bacteria. Since both of them are Gram negative cells, $1 \mathrm{ml}$ aliquots of the sample were fixed in freshly prepared $4 \%$ paraformaldehyde (PFA) for $1-3 \mathrm{~h}$ at $4{ }^{\circ} \mathrm{C}$. After fixation, cells were washed with Phosphate Buffered Saline (PBS), resuspended in PBS-absolute ethanol 
$(1: 1, \mathrm{v} / \mathrm{v})$ and stored at $20{ }^{\circ} \mathrm{C}$ [32]. Hybridizations were carried out as described in Amann et al. [33]. Oligonucleotide sequences employed in this study are listed in the Appendix (Table A.1). Hybridized samples were observed under epifluorescence microscope (Leica DM2500).

\subsection{Statistical analysis}

All analytical determinations were performed in duplicate. The results are given as the average with its corresponding standard deviation.

The data were analysed for significance $(p$-value $=0.05)$ using an analysis of variance (ANOVA) carried out by SPSS 16.1.

\section{Results and Discussion}

\subsection{Effect of light}

The first set of experiments (Exp. L1, Exp. L2 and Exp. L3) were aimed at evaluating the nutrient removal efficiency and the biomass productivity under 3 different light intensities: 40,85 and $125 \mu \mathrm{E} \cdot \mathrm{m}^{-2} \cdot \mathrm{s}^{-1}$, respectively; maintaining constant temperature and working conditions. Table 2 shows the results obtained in this section.

Experiment L1 consisted of 17 days during which temperature remained stable $(22 \pm 1$

${ }^{\circ} \mathrm{C}$ ) and four fluorescent lamps were used to supply a light intensity of $40 \mu \mathrm{E} \cdot \mathrm{m}^{-2} \cdot \mathrm{s}^{-1}$. As can be seen in Figure 2, ammonium concentration in Exp. L1 started at $6.5 \mathrm{mgN} \cdot \mathrm{L}^{-1}$ and the sum of nitrite and nitrate at $4.4 \mathrm{mgN} \cdot \mathrm{L}^{-1}$ after the inoculation time. Immediately, the ammonium concentration started to decrease until it was almost depleted (ARE of 97.2 $\pm 2.3 \%$ ), and the nitrite and nitrate began to accumulate, exceeding the nitrogen 
discharge limit $\left(10 \mathrm{mgN} \cdot \mathrm{L}^{-1}\right)$ at day 5 . At the end of the Exp. L1, the concentration of nitrite and nitrate remained approximately stable around $13 \mathrm{mgN} \cdot \mathrm{L}^{-1}$.

The accumulation of these two nitrogen species can be explained by the consumption of ammonium by ammonium-oxidizing bacteria (instead of microalgae). The presence of bacteria in the inoculum and the reduction of light intensity supply from $85 \mu \mathrm{E} \cdot \mathrm{m}^{-2} \cdot \mathrm{s}^{-1}$ (during the inoculation) to $40 \mu \mathrm{E} \cdot \mathrm{m}^{-2} \cdot \mathrm{s}^{-1}$ (in Exp. L1) limited microalgae growth in Exp.L1. Consequently, bacteria were able to compete with microalgae for ammonium uptake and nitrite and nitrate accumulated until equilibrium was established. Even though it is widely accepted that microalgae consume other nitrogen compounds different than ammonium; for instance, nitrogen oxides [34], the consumption of nitrite and nitrate was not noticeable in this experiment.

Because of the nitrification process, the ammonium removal efficiency only due to microalgae activity was calculated: $73.9 \pm 2.9 \%$. It must be highlighted that, even though a bacteria proliferation occurred, the phosphate removal efficiency remained at high values throughout Exp. L1 $(98.6 \% \pm 1.4)$, yielding a low P concentration along Exp. L1 (see Figure 2). Considering only the amount of ammonium consumed by microalgae, the $\mathrm{N}: \mathrm{P}$ molar ratio remained at $13.3 \pm 0.7$ in Exp. 1.

The nitrification process also reduced the ammonium removal rate by microalgae, which showed a statistical significant difference $(\mathrm{p}$-value $<0.05)$ with the total ammonium removal rate: $3.47 \pm 0.95 \mathrm{mgN} \cdot \mathrm{L}^{-1} \cdot \mathrm{d}^{-1}$ and $5.28 \pm 0.93 \mathrm{mgN} \cdot \mathrm{L}^{-1} \cdot \mathrm{d}^{-1}$, respectively. Regarding phosphorus, PRR was $0.61 \pm 0.14 \mathrm{mgP} \cdot \mathrm{L}^{-1} \cdot \mathrm{d}^{-1}$. These values are considerably low, since Ruiz-Martínez et al. [5] reported significant higher nutrient removal rates: $\mathrm{mARR}$ of $19.5 \mathrm{mgN} \cdot \mathrm{L}^{-1} \cdot \mathrm{d}^{-1}$ and $\mathrm{PRR}$ of $3.7 \mathrm{mgP} \cdot \mathrm{L}^{-1} \cdot \mathrm{d}^{-1}$ in a culture of Scenedesmus spp. fed by an AnMBR effluent at BRT of 2 days. This fact suggests the 
system could be nutrient-limited due to the relatively high BRT ( 8 days), since the nutrient efficiency in Exp. 1 was close to $100 \%$ for both ARR and PRR (see Table 2).

Exp. L2 consisted of 29 days during which light intensity was the only operational condition modified, increasing from 40 to $85 \mu \mathrm{E} \cdot \mathrm{m}^{-2} \cdot \mathrm{s}^{-1}$. ARE and PRE remained at high values, similar to the values obtained in Exp. L1 $(99.8 \pm 0.2 \%$ and $99.2 \pm 0.7 \%$, respectively). Nevertheless, a statistically significant increase in mARE from $73.9 \pm$ $2.9 \%$ to $99.3 \pm 0.2 \%$ (p-value $<0.05)$ occurred. This fact indicates that increasing the light intensity of the system enhanced microalgae performance, giving algae an advantage in the microalgae-bacteria competition. Raising light intensity accelerates the microalgae metabolism as long as it remains under the optimum value. Hence, in these conditions, the microalgae were able to consume ammonium faster than the nitrifying bacteria. This is in accordance with Lydmark [35], who reported a higher ammonium uptake for Scenedesmus obliquus than for ammonia-oxidizing bacteria: 18.5 - 82.1 fmolN $\cdot \operatorname{cell}^{-1} \cdot \mathrm{h}^{-1}$ and $0.03-53 \mathrm{fmolN} \cdot \mathrm{cell}^{-1} \cdot \mathrm{h}^{-1}$, respectively. The nitrification rate dropped and net nitrogen removal reached high values $(99.3 \pm 0.2 \%)$. As can be seen in Figure 2, from day 21 until the end of Exp. L2, the sum of nitrite and nitrate concentrations stayed lower than $0.6 \mathrm{ppm}$, which enabled meeting by far the legal requirements $\left(10 \mathrm{mgN} \cdot \mathrm{L}^{-1}\right)$.

Figure 3 shows nitrite and nitrate evolution in the early stages of Exp. L2 (experimental results) and the estimated nitrite and nitrate concentration trends due to nutrient washout only, leaving the other processes (nitrification, nitrite and nitrate uptake) out of consideration (continuous line). As can be observed in Figure 3, the experimental nitrite and nitrate concentrations were fairly lower than those estimated by washout. Thus, 
microalgae could have consumed this amount of nitrite and nitrate when ammonium was depleted.

It is known that microalgae prefer ammonium as a nitrogen source $[16,36]$. In fact, several studies have pointed out that nitrate consumption by microalgae does not occur until the ammonium is nearly completely removed [37], since the nitrate conversion to ammonium inside the cell requires energy [11]. Hence, it seems that microalgae were able to consume nitrite and nitrate in Exp. L2 because the ammonium concentration was low and because the light received in this case could have provided enough energy for the nitrate conversion to ammonium. On the other hand, in Exp. L1, due to the lack of energy at a low light intensity, algae were unlikely to absorb nitrite and nitrate and these nitrogen species were therefore accumulated (see Figure 2).

In Exp. L2 mARR also increased and reached a similar value than ARR: $6.43 \pm 1.49$ $\mathrm{mgN} \cdot \mathrm{L}^{-1} \cdot \mathrm{d}^{-1}$ and $6.44 \pm 1.47 \mathrm{mgN} \cdot \mathrm{L}^{-1} \cdot \mathrm{d}^{-1}$, respectively (p-value $>0.05$ ); which reaffirms the dominance of microalgae in the ammonium competition with nitrifying bacteria. In Exp. L2, ARR and PRR were higher than in Exp. L1, because the nutrient load in this case was also higher (see Table 2).

Exp. L3 consisted of 34 days during which light intensity was further increased, from 85 to $125 \mu \mathrm{E} \cdot \mathrm{m}^{-2} \cdot \mathrm{s}^{-1}$. The calculated ARE and PRE were slightly higher: $99.9 \pm 0.2 \%$ and $99.5 \pm 0.2 \%$, respectively; but the differences with Exp. L2 were not statistically significant ( $p$-value $>0.05$ ). Higher mARE was also observed, reaching the maximum mARE value of the three experiments: $99.3 \pm 0.4 \%$ (see Table 2). However, the higher mARE was not statistically significant either ( $p$-value $>0.05$ ). The small differences between Exp. L2 and L3 in terms of removal efficiencies could have been due to nutrient limitation. Under the fixed BRT of 8 days, the culture was able to remove 
nearly $100 \%$ of the nitrogen and phosphorus in both Exp. L2 and Exp. L3. Nevertheless, the light intensity rise caused a significant increase in the biomass concentration from $658 \pm 35$ to $755 \pm 79 \mathrm{mgVSS} \cdot \mathrm{L}^{-1}$ (p-value $\left.<0.05\right)$. It is possible that this biomass increment was due to the higher nutrient load in Exp L3 compared to Exp. L2 (see Table 2). This higher nutrient load would also explain the higher mARR, ARR and PRR attained in Exp. L3 compared to Exp. L2 (see Table 2).

In order to verify the light effect on nutrient removal, nutrient concentration was monitored during one feed cycle in both experiments. As can be seen in Figure 4, an increase in light intensity from 85 to $125 \mu \mathrm{E} \cdot \mathrm{m}^{-2} \cdot \mathrm{s}^{-1}$ raised the one-cycle ammonium removal rate by $73 \%$ (from 29.7 to $51.7 \mathrm{mgN} \cdot \mathrm{L}^{-1} \cdot \mathrm{h}^{-1}$, respectively). These values correspond to specific one-cycle ammonium removal rates of 42.7 and $75.9 \mathrm{mgN} \cdot \mathrm{gVSS}^{-}$ ${ }^{1} \cdot \mathrm{d}^{-1}$, respectively, or 194.3 and $338.6 \mathrm{fmolN} \cdot \mathrm{cell}^{-1} \cdot \mathrm{h}^{-1}$, respectively. These values are much higher than those obtained by Lydmark [35] for Scenedesmus obliquus: 18.5 82.1 fmolN $\cdot \operatorname{cell}^{-1} \cdot \mathrm{h}^{-1}$. Phosphorus was consumed very fast and not enough data was available to calculate the corresponding removal rate (data not shown). These results suggest that the system reveals a higher capacity to remove nitrogen and therefore was nutrient-limited. Therefore, the maximum mARR and PRR obtained: $6.92 \pm 1.05$ $\mathrm{mgN} \cdot \mathrm{L}^{-1} \cdot \mathrm{d}^{-1}$ and $0.90 \pm 0.16 \mathrm{mgP} \cdot \mathrm{L}^{-1} \cdot \mathrm{d}^{-1}$, respectively, are not representative of the maximum capacity of the system to remove nutrients. Lower BRT should be tested to verify the maximum nutrient load that the system is able to remove from the AnMBR effluent to maintain meeting the effluent standards.

In the appendix, Figure A.1 shows the evolution in biomass productivity in Exp. L1, L2 and L3. Two remarkable increases in the biomass productivity were observed: from $50.5 \pm 9.6$ to $80.3 \pm 6.5 \mathrm{mgVSS} \cdot \mathrm{L}^{-1} \cdot \mathrm{d}^{-1}$ between Exp. L1 to L2 and from $80.3 \pm 6.5$ to 
$94.3 \pm 7.9 \mathrm{mgVSS} \cdot \mathrm{L}^{-1} \cdot \mathrm{d}^{-1}$ between Exp. L2 to L3. These results suggest that biomass productivity increases as light intensity rises, as long as it remains under a light intensity of $125 \mu \mathrm{E} \cdot \mathrm{m}^{-2} \cdot \mathrm{s}^{-1}$. Besides, Figure A.1 shows that the biomass productivity rise from Exp. L1 to L2 is more pronounced than the rise from Exp. L2 to L3. This is maybe due to the nutrient limitation which the culture was being carried out from day 21 on, as it has been already mentioned (see Figure 2). In fact, Pancha et al. [38] obtained a significant decrease in biomass productivity from a maximum value of $32.01 \mathrm{mgVSS} \cdot \mathrm{L}^{-}$ ${ }^{1} \cdot \mathrm{d}^{-1}$ when the nitrogen in the medium was $247 \mathrm{mgN} \cdot \mathrm{L}^{-1}$, to $8.48 \mathrm{mgVSS} \cdot \mathrm{L}^{-1} \cdot \mathrm{d}^{-1}$ at nitrogen starvation conditions. On their behalf, Sarat Chandra et al. [39] reported a biomass productivity of $50 \mathrm{mgVSS} \cdot \mathrm{L}^{-1} \cdot \mathrm{d}^{-1}$ in a culture of Scenedesmus obtusus fed by a modified Bold Basal medium with a light intensity of $60 \mu \mathrm{E} \cdot \mathrm{m}^{-2} \cdot \mathrm{s}^{-1}$, very similar to the value obtained in the present study for Exp. L1: $50.5 \pm 9.6 \mathrm{mgVSS} \cdot \mathrm{L}^{-1} \cdot \mathrm{d}^{-1}$. Nevertheless, Ruiz-Martínez et al. [5] reported considerably higher biomass productivity: $234 \mathrm{mgVSS} \cdot \mathrm{L}^{-1} \cdot \mathrm{d}^{-1}$. As already mentioned, the results of Ruiz-Martínez et al. [5] were attained at a higher nutrient load. Therefore, it is deduced that higher productivity in Exp. L3 of the present study could have been expected if the nutrient load would have been higher.

Analysing the entire light intensity experimental period (Exp. L1, L2 and L3), it could be concluded that a light intensity increase from 40 to $85 \mu \mathrm{E} \cdot \mathrm{m}^{-2} \cdot \mathrm{s}^{-1}$ seriously reduced the nitrification rate and increased the net nitrogen removal by microalgae from $73.9 \%$ \pm 2.9 in Exp. L1 to $99.3 \% \pm 0.2$ in Exp. L2. For this reason, it was assumed that microalgae growth was limited due to the competition of nitrifying bacteria for ammonium in Exp. L1, in which mARE $(73.9 \% \pm 2.9)$ was substantially lower than $\operatorname{ARE}(97.2 \% \pm 4.9)$, implying that $23.3 \% \pm 5.1$ of the total ammonium consumed was 
used by nitrifying bacteria. On the other hand, microalgae were not limited by bacteria after light intensity was raised in Exp. L2 and L3, since the mARE was similar to ARE and close to $100 \%$ (see Table 2). It is remarkable that no addition of a nitrification inhibitor was needed for bacteria inhibition, unlike which has been reported by other authors [40]. Hence, supplying the proper light intensity may reduce the use of chemicals in wastewater treatment by microalgae. Regarding phosphorous, high PRE was reached in all the experiments: $98.6 \% \pm 1.4,99.2 \% \pm 0.7$ and $99.5 \% \pm 0.2$ in Exp. L1, L2 and L3, respectively; thus no significant differences in PRE were registered (pvalue $>0.05)$.

Everything mentioned above can be supported by the fact that eukaryotic cell density rose as light intensity increased $\left(6.55 \pm 0.04,11.90 \pm 1.59\right.$ and $14.61 \pm 2.91\left(\times 10^{9}\right)$ cells $\cdot \mathrm{L}^{-1}$, in Exp. L1, L2 and L3, respectively). Cell counts did not reveal any variation in culture composition since Scenedesmus spp. remained as dominant genus $(>99 \%$ during all the experiments). Regarding the samples observed under the epifluorescence microscope, even though microalgae were dominant, the FISH technique allowed us to identify some groups of nitrifying bacteria in Exp. L1 (see Figure 6a and 6b). On the other hand, the bacteria population was negligible in Exp. L2 (see Figure 6c and 6d). Similarly to the results obtained for cell density, VSS rose as light intensity increased: $429 \pm 15,658 \pm 35$ and $755 \pm 79 \mathrm{mg} \cdot \mathrm{VSS} \mathrm{L}^{-1}$, in Exp. L1, L2 and L3, respectively, which is an indicator that most of the biomass corresponded to eukaryotic microalgae. Moreover, the fact that the chlorophyll content dropped from Exp.L1 to Exp. L2 and Exp. L3 $\left(4.18 \pm 0.99,2.44 \pm 0.59\right.$ and $1.44 \pm 0.44 \mathrm{mg} \cdot \mathrm{gVSS}^{-1}$, respectively) confirmed the results observed by Reynolds [22] and Chen et al. [41]. Reynolds [22] stated that at low levels of irradiance, one of the mechanisms used to enhance photosynthetic 
potential is to increase cell-specific light-harvesting capacity, which involves synthesis in higher quantities of chlorophyll. On the other hand, Chen et al. [41] noticed that at higher light intensities, microalgae reduce chlorophyll content in order to reduce photon absorption and to protect themselves against photoinhibition, which agrees with the results obtained in the present study. Sarat Chandra et al. [39] also obtained a higher chlorophyll concentration with a light intensity of $30 \mu \mathrm{mol} \cdot \mathrm{m}^{-2} \cdot \mathrm{s}^{-1}$ compared to 60 $\mu \mathrm{mol} \cdot \mathrm{m}^{-2} \cdot \mathrm{s}^{-1}$ for Scenedesmus obtusus.

In Exp. L1, L2 and. L3, the N:P ratio obtained for microalgae was $13.3 \pm 0.7,18.5 \pm 1.1$ and $17.6 \pm 1.7$, respectively. However, the culture did not suffer a significant change in microalgae composition during the entire experimental period as Scenedesmus spp. remained as dominant genus $(>99 \%)$. It is therefore possible that in Exp. L1 the microalgae consumed higher amount of phosphorus in proportion, accumulating it as internal polyphosphate reserves. According to Powell et al. [42], microalgae are able to store large amounts of phosphorus in order to accumulate intracellular polyphosphate. Theoretically, this polyphosphate is able to sustain three or even four cell doublings without taking up any more phosphorus [22]. It was assumed that no phosphorus precipitation took place, since the culture $\mathrm{pH}$ values $(7.4 \pm 0.1)$ and low ions concentration made this precipitation unlikely.

It has been shown that the operating conditions (temperature, $\mathrm{pH}$, nutrient loading and BRT) clearly have an effect on the microalgae-bacteria competition. In Exp. L1, the light intensity supplied was too low, and the system was unable to remove nitrogen under the discharge limits. On the other hand, Exp. L2 achieved ARE and PRE values close to $100 \%$. In Exp. L3 (with considerably higher light intensity) the rise in these values was not significant ( $p$-value $>0.05$ ). In order to choose the most efficient PBR 
configuration, the nutrient removal rate:light irradiance ratio (both mARR/I and PRR/I) was calculated. This parameter informs about the amount of nutrients that microalgae absorb for every mole of photons that they receive. In Exp. L2 and. L3, the mARR/I obtained was $76.7 \pm 17.8$ and $59.0 \pm 8.9 \mathrm{mgN} \cdot$ molphoton $^{-1}$, respectively; meanwhile the PRR/I resulted in Exp. L2 and. L3 were $15.5 \pm 3.5,9.3 \pm 1.9$ and $7.6 \pm 1.4$ $\mathrm{mgP} \cdot$ molphoton $^{-1}$, respectively. These results suggest that the use of light by the culture was more efficient in Exp. L2, when lower light intensity was supplied to the system. For this reason, Exp. L2 might be the most cost-effective configuration to achieve an efficient nutrient removal, which implies meeting the discharge limits for both nitrogen and phosphorus. Regarding biomass productivity, Exp. L3 showed a significant increase compared to Exp. L2; although this increment could have been influenced by the higher nutrient load received in Exp. $\mathrm{L} 3\left(57.3 \pm 5.0 \mathrm{mgN} \cdot \mathrm{d}^{-1}\right.$ and $\left.7.4 \pm 0.7 \mathrm{mgP} \cdot \mathrm{d}^{-1}\right)$ compared to Exp. L2 $\left(56.2 \pm 8.4 \mathrm{mgN} \cdot \mathrm{d}^{-1}\right.$ and $\left.6.8 \pm 0.7 \mathrm{mgP} \cdot \mathrm{d}^{-1}\right)$. Thus, it cannot be assured that light intensity is the main factor that made obtain higher biomass productivity when the light supplied was increased from $85 \mu \mathrm{E} \cdot \mathrm{m}^{-2} \cdot \mathrm{s}^{-1}$ to $125 \mu \mathrm{E} \cdot \mathrm{m}^{-2} \cdot \mathrm{s}^{-1}$.

\subsection{Effect of temperature}

The goal of this second set of experiments was to check whether microalgae were able to dominate the ammonium competition under different temperatures with the same light intensities that were previously studied and where microalgae took advantage over ammonium oxidizing bacteria: $85 \mu \mathrm{E} \cdot \mathrm{m}^{-2} \cdot \mathrm{s}^{-1}$ and $125 \mu \mathrm{E} \cdot \mathrm{m}^{-2} \cdot \mathrm{s}^{-1}$ (see Exp. L2 and L3). The other operational parameters $(\mathrm{pH}, \mathrm{BRT}, \mathrm{HRT})$ remained at the same values than in Exp. L1, L2 and L3. 
Figure 5 shows the nutrient concentration and the temperature evolution with daily maximum and minimum temperatures during Exp. T1 and T2.

As can be seen in Figure 5a, Exp. T1 had maximum daily temperatures (marked as vertical lines) of 27 and $28{ }^{\circ} \mathrm{C}$, respectively, the first two days of the experiment. From the second day on, the nitrite-nitrate concentration started to increase, suggesting that a proliferation of nitrifying bacteria was taking place although the temperature remained almost constant until day 11 (with the exception of day 6, see Figure 5a). It is important to notice that ammonium concentration remained negligible during all Exp. T1. Hence, it can be deduced that punctual variations of the culture temperature at a light intensity of $85 \mu \mathrm{E} \cdot \mathrm{m}^{-2} \cdot \mathrm{s}^{-1}$ are enough to favour ammonium oxidizing bacteria growth with regard to microalgae growth. This caused a remarkable decreased in mARE, which was $73.6 \%$ at the end of Exp. T1; meanwhile, in Exp. L2, with the same light intensity and controlled temperature, mARE had high values: $98.3 \pm 1.9 \%$. A decrease in mARR/I was also observed: from $76.7 \pm 17.8 \mathrm{mgN} \cdot \mathrm{mol}^{-1}$ in Exp. L2 to $59.8 \pm 12.8 \mathrm{mgN} \cdot \mathrm{mol}^{-1}$.

On the other hand, the removal of phosphorus during this period was not affected by the AOB proliferation, since it remained at negligible concentrations during the entire Exp. T1 (see Figure 5a).

Regarding Exp. T2, it can be observed that a continuous rise in nitrite and nitrate concentration occurred after day 8 (see Figure $5 \mathrm{~b}$ ), reaching a concentration of nitrite and nitrate of $36.1 \mathrm{mgN} \cdot \mathrm{L}^{-1}$ the day 23 . It is remarkable that these compounds patterns are similar to those shown in Exp. T1, suggesting that nitrifying bacteria proliferation started at that moment and continued until the end of Exp. T2 (see Figure 5b). By the end of Exp. T2, the culture was dominated by bacteria, which implied, apart from the high concentration of nitrite and nitrate, that the concentration of phosphate in the 
culture was not negligible as occurred in the rest of experiments. In fact, in day 29 of Exp. T2, the phosphate concentration was higher than $2 \mathrm{mgP} \cdot \mathrm{L}^{-1}$. This provoked that mARE and PRE decreased from nearly $100 \%$ when the temperature was controlled (Exp. L3), to $24.2 \%$ and $63.7 \%$, respectively at the end of Exp. T2. A decrease in mARR/I was also observed: from $59.0 \pm 8.9 \mathrm{mgN} \cdot \mathrm{mol}^{-1}$ in Exp. L3 to $36.2 \pm 17.6$ $\mathrm{mgN} \cdot \mathrm{mol}^{-1}$ in Exp. T2. Thus, when temperature rose above a limit temperature, microalgae were not able to use the light energy for nitrogen removal as efficiently as they did when temperature was under control.

It must be highlighted that in Exp. T2 (light intensity of $125 \mu \mathrm{E} \cdot \mathrm{m}^{-2} \cdot \mathrm{s}^{-1}$ ), the proliferation of nitrifying bacteria (inferred through the nitrite and nitrate accumulation) started to take place from a maximum temperature of $32{ }^{\circ} \mathrm{C}$; meanwhile in Exp. T1 (light intensity of $85 \mu \mathrm{E} \cdot \mathrm{m}^{-2} \cdot \mathrm{s}^{-1}$ ), the proliferation of bacteria started to occur from a maximum temperature of $28{ }^{\circ} \mathrm{C}$. On the other hand, in Exp. L1 (light intensity of 40 $\left.\mu \mathrm{E} \cdot \mathrm{m}^{-2} \cdot \mathrm{s}^{-1}\right)$, the proliferation of bacteria occurred at a maximum temperature of $23{ }^{\circ} \mathrm{C}$. This suggests that the higher the light intensity supplied to the PBR is, the higher the temperature is needed for the nitrifying bacteria to proliferate.

Cabello et al. [43] verified that the optimum temperature for Scenedesmus obtusiusculus was $35{ }^{\circ} \mathrm{C}$ under normal growth conditions and $28.5{ }^{\circ} \mathrm{C}$ under nitrogen-limiting conditions. It therefore seems that a pure microalgae culture is able to grow successfully within the temperature range registered in Exp. T1 and T2. However, in the present study, due to the algae-bacteria competition, these temperatures reported by Cabello et al. [43] were over the optimum value for microalgae growth.

Summarising, it can be concluded that the operational conditions in these experiments of 85 and $125 \mu \mathrm{E} \cdot \mathrm{m}^{-2} \cdot \mathrm{s}^{-1}$ and achieving temperatures above $28{ }^{\circ} \mathrm{C}$ in the case of 85 
$\mu \mathrm{E} \cdot \mathrm{m}^{-2} \cdot \mathrm{s}^{-1}$ (Exp. T1), and above $32{ }^{\circ} \mathrm{C}$ in the case of $125 \mu \mathrm{E} \cdot \mathrm{m}^{-2} \cdot \mathrm{s}^{-1}($ Exp. T2) reduce the microalgae activity and allow the nitrifying bacteria growth; making the culture unable to remove nitrogen efficiently.

To verify that nitrifying bacteria proliferated in both Exp. T1 and T2, the FISH technique was used. The FISH technique identified nitrifying bacteria in Exp. T1 (see Figure 6e), as well as detecting the presence of other bacteria in T1 and T2 (see Figure 6f and 6g). The rise in filamentous Cyanobacteria was observed in Exp. T2 (see Figure 6h), which is in concordance with Zhu et al. [44], who reported that high temperatures stimulated the growth of cyanobacteria in water bodies, especially at low nutrient levels.

\section{Conclusions}

It has been demonstrated that using a microalgae-bacteria culture as tertiary treatment allows nutrient effluent standards to be met, as long as nitrification is controlled and the culture is not dominated by bacteria. These limits were not exceeded in Exp. L2 and L3, when microalgae were the main organism in the culture. On the other hand, the presence of nitrifying bacteria in the PBR has been shown to clearly reduce the nitrogen removal rate of the system, since they compete with microalgae for ammonium. In Exp. L1, T1 and T2, when nitrifying bacteria grew remarkably, the discharge limit for nitrogen was not achieved, and for phosphorus was met only in Exp. L1 and T1. Hence, if maximum performance of microalgae is required, the optimal conditions for their growth must be supplied in order for microalgae to dominate the competition.

Increasing light intensity favoured microalgae growth and the advantage of algae over the nitrifying bacteria. In fact, biomass productivity raised from $50.5 \pm 9.6 \mathrm{mgVSS} \cdot \mathrm{L}^{-}$ ${ }^{1} \cdot \mathrm{d}^{-1}$ in Exp. L1 to $80.3 \pm 6.5 \mathrm{mgVSS} \cdot \mathrm{L}^{-1} \cdot \mathrm{d}^{-1}$ in Exp. L2 and $94.3 \pm 7.9 \mathrm{mgVSS} \cdot \mathrm{L}^{-1} \cdot \mathrm{d}^{-1}$ 
in Exp. L3; which implied that nitrogen removal efficiency by microalgae reached high values (over $99.0 \%$ ) in Exp. L2 and L3.

It was observed that the PBR removed nitrogen and phosphorus efficiently when the temperature was around $22{ }^{\circ} \mathrm{C}$. In this situation, no significant proliferation of nitrifying bacteria was observed. When the temperature rose, bacteria took advantage for ammonium uptake and thus the microalgal culture could not remove enough nutrients to meet the effluent limits established in the European Union Council Directive 91/271/EEC.

\section{ACKNOWLEDGEMENTS}

This research work was possible thanks to Project CTM2011-28595-C02-01/02 (funded by the Spanish Ministry of Economy and Competitiveness jointly with the European Regional Development Fund and the Generalitat Valenciana GVA-ACOMP2013/203). This research was also supported by the Spanish Ministry of Education, Culture and Sport via a pre doctoral FPU fellowship to the first author (FPU14/05082).

\section{REFERENCES}

[1] Jeison D. Anaerobic membrane bioreactors for wastewater treatment: feasibility and potential applications [dissertation]. Wageningen, (Netherlands): Wageningen University; 2007.

[2] Giménez JB, Robles A, Carretero L, et al. Experimental study of the anaerobic urban wastewater treatment in a submerged hollow-fibre membrane bioreactor at pilot scale, Bioresour. Technol. 2011;102:8799-8806. 
[3] Huang Z, Ong SL, Ng HY, Submerged anaerobic membrane bioreactors for lowstrength wastewater treatment: Effect of HRT and SRT on treatment performance and membrane fouling. Water Res. 2011;45;705-713.

[4] European Union. Council Directive 91/271/EEC of 21 May 1991 concerning urban waste-water treatment. OJ L 135, 30.5.1991, p. 40-52.

[5] Ruiz-Martínez A, Martin Garcia N, Romero I, et al. Microalgae cultivation in wastewater: nutrient removal from anaerobic membrane bioreactor effluent. Bioresour. Technol. 2012;126:247-253.

[6] Chisti Y. Biodiesel from microalgae. Biotechnol. Adv. 2007;25:294-306.

[7] Rawat I, Bhola V, Ranjith Kumar R, et al. Improving the feasibility of producing biofuels from microalgae using wastewater. Environ. Technol. 2013;34(13-14):17651775.

[8] Collet P, Hélias A. Life Cycle assessment of microalgae culture coupled to biogas production. Bioresour. Technol. 2011;102:207-214.

[9] Milledge JJ. Commercial application of microalgae other than as biofuels: a brief review. Rev. Environ. Sci. Biotechnol. 2011;10:31-41.

[10] Posadas E, García-Encina PA, Soltau A, et al. Carbon and nutrient removal from centrates and domestic wastewater using algal-bacterial biofilm bioreactors. Bioresour. Technol. 2013;139:50-58.

[11] Podevin M, de Francisci D, Holdt SL, et al. Effect of nitrogen source and acclimatization on specific growth rates of microalgae determined by a high-throughput in vivo microplate autofluorescence method. J. Appl. Phycol. 2015;27:1415-1423. 
[12] Meseck SL, Smith BC, Wikfors GH, et al. Nutrient interactions between phytoplankton and bacterioplankton under different carbon dioxide regimes. J. Appl. Phycol. 2007;19:229-237.

[13] Risgaard-Petersen N, Nicolaisen MH, Revsbech NP, et al. Competition between ammonia oxidizing bacteria and benthic microalgae. Appl. Environ. Microb. $2004 ; 70: 5528-5537$.

[14] Tiquia-Arashiro SM, Mormile M. Sustainable Technologies: Bioenergy and Biofuel from Biowaste and Biomass. Environ. Technol. 2013;34(13-14):1637-1638.

[15] Jordan B. The effects of ultraviolet-B radiation on plants: a molecular perspective. Advances in Botanical Research. 1996;22:97-162.

[16] Znad H, Naderi G, Ang HM, et al. CO2 biomitigation and biofuel production using microalgae: photobioreactors developments and future directions. In: Nawaz Z, Naveed S, editors. Advances in Chemical Engineering. Sydney (Australia): Elseviewer Inc; 2012. p. 229-244.

[17] Hindersin S. Photosynthetic efficiency of microalgae and optimization of biomass production in photbioreactors [dissertation]. Hamburg (Germany): Universität Hamburg; 2013.

[18] Koç C, Anderson GA, Kommareddy A. Use of Red and Blue Light-Emitting Diodes (LED) and Fluorescent Lamps to Grow Microalgae in a Photobioreactor. The Israeli Journal of Aquaculture. 2013;65:797-804.

[19] Martínez ME, Sánchez S, Jiménez JM, et al. Nitrogen and phosphorus removal from urban wastewater by the microalga Scenedesmus obliquus. Bioresour. Technol. 2000;73:263-272. 
[20] Li X, Hu HY, Zhang YP. Growth and lipid accumulation properties of a freshwater microalga Scenedesmus sp. under different cultivation temperature. Bioresour. Technol. 2011;102:3098-3102.

[21] Robles Á, Durán F, Ruano et al. Instrumentation, control, and automation for submerged anaerobic membrane bioreactors. Environ. Technol. 2015;36(14):17951806.

[22] Reynolds CS. The Ecology of Phytoplankton (Ecology, Biodiversity and Conservation). Cambridge: Cambridge University Press; 2006.

[23] Küster E, Dorusch F, Altenburguer R. Effects of hydrogen sulfide to Vibrio fischeri, Scenedesmus vacuolatus and Daphnia magna. Environ. Toxicol. and Chem. 2005;24(10):2621-2629.

[24] Park J, Jin HF, Lim BR, et al. Ammonia removal from anaerobic digestion effluent of livestock waste using green alga Scenedesmus sp. Bioresour. Technol. 2010;101:8649-8657.

[25] McGinn PJ, Dickinson KE, Park KC, et al. Assessment of the bioenergy and bioremediation potentials of the microalga Scenedesmus sp. AMDD cultivated in municipal wastewater effluent in batch and continuous mode. Algal Res. 2012;1:155165.

[26] Mara D, Horan N. Handbook of Water and Wastewater Microbiology. University of Leeds (United Kingdom): School of Civil Engineering; 2003.

[27] Vonshak A, Torzillo G. Environmental Stress Physiology. In: Richmond A, editor. Handbook of Microalgal Culture: Biotechnology and Applied Phycology. Australia: Blackwell Publishing Ltd; 2004. p. 57-82. 
[28] APHA, AWWA, WPCF, Standard Methods for the Examination of Waters and Wastewaters, 21st ed. Washington DC, (USA): American Public Health Association/American Water Works Association/Water Environmental Federation; 2005.

[29] Jeffrey SW, Humphrey GF. New spectrophotometric equations for determining chlorophylls $a, b, c 1$ and $c 2$ in higher plants, algae and natural phytoplankton. Biochem. Physiol. Pflanzen (BPP), Bd. 1975;167:191-194.

[30] Laliberté G, Lessard P, de la Noüe J, et al. Effect of phosphorus addition on nutrient removal from wastewater with the cyanobacterium Phormidium bohneri. Bioresour. Technol. 1997;59:227-233.

[31] Pachés M, Romero I, Hermosilla Z, et al. PHYMED: An ecological classification system for the Water Framework Directive based on phytoplankton community composition. Ecol. Indic. 2012;19:15-23.

[32] Harmsen HJM, Kengen HMP, Akkermans ADL, et al. Detection and localization of syntrophic propionate-oxidizing bacteria in granular sludge by in situ hybridization using 16S rRNA-based oligonucleotide probes. App. Environ. Microbiol. $1996 ; 62: 1656-1663$.

[33] Amann R, Binder BJ, Olson RJ, et al. Combination of 16s ribosomal-RNA-targeted oligonucleotide probes with flow cytometry for analyzing mixed microbial-populations. Appl. Environ. Microbiol. 1990;56:1919-1925.

[34] Li X, Hu HY, Gan K. Growth and nutrients removal properties of a freshwater microalga Scenedesmus sp. LX1 under different kinds of nitrogen sources. Ecol. Eng. 2010;36:379-381. 
[35] Lydmark P. Population dynamics of nitrifying bacteria in biological wastewater treatment [dissertation]. Sweden: Department of Cell and Molecular Biology, Microbiology, Göteborg University; 2006.

[36] Wang L, Min M, Li Y, et al. Cultivation of green algae Chlorella sp. in different wastewaters from municipal wastewater treatment plant. Appl. Biochem. BioTechnol. 2010;164:1174-1186.

[37] Hii YS, Soo CL, Chuah TS, et al. Interactive effect of ammonia and nitrate in the nitrogen uptake by Nannochloropsis sp. Journal of Sustainability Science and Management. 2011;6:60-68.

[38] Pancha I, Chokshi K, George B, et al. Nitrogen stress triggered biochemical and morphological changes in the microalgae Scenedesmus sp. CCNM 1077. Bioresour. Technol. 2014;156:146-154.

[39] Sarat Chandra T, Deepak RS, Maneesh Kumar M, et al. Evaluation of indigenous fresh water microalga Scenedesmus obtusus for feed and fuel applications: Effect of Carbon dioxide, light and nutrient sources on growth and biochemical characteristics. Bioresour. Technol. 2016;207:430-439.

[40] Krustok I, Odlare M, Truu J, et al. Inhibition of nitrification in municipal wastewater-treating photobioreactors: Effect on algal growth and nutrient uptake. Bioresour. Technol. 2016;202:238-243.

[41] Chen X, Goh QY, Tan W, et al. Lumostatic strategy for microalgae cultivation utilizing image analysis and chlorophyll a content as design parameters. Bioresour. Technol. 2011;102:6005-6012.

[42] Powell N, Shilton A, Chisti Y, et al. Towards a luxury uptake process via microalgae - Defining the polyphosphate dynamics. Water Res. 2009;43:4207-4213. 
[43] Cabello J, Toledo-Cervantes A, Sánchez L, et al. Effect of the temperature, $\mathrm{pH}$ and irradiance on the photosynthetic activity by Scenedesmus obtusiusculus under nitrogen replete and deplete conditions. Bioresour. Technol. 2015;181:128-135.

[44] Zhu W, Wan L, Zhao L. Effect of nutrient level on phytoplankton community structure in different water bodies. Journal of Environmental Sciences. 2010;22(1):3239.

[45] Daims H, Brühl A, Amann R, et al. The domain specific probe EUB338 is insufficient for the detection of all bacteria: development and evaluation of a more comprehensive probe set. Syst. Appl. Microbiol. 1999;22:434-444.

[46] Alonso JL, Borrás L, Amorós I. Improved in situ hybridization efficiency of nitrifying bacteria with locked-nucleic-acid incorporated DNA probe. Specialised Conference on Microbial Population Dynamics in Biological. ASPD5 IWA Int.; May 2009; Aalborg (Denmark).

[47] Daims H, Nielsen JL, Nielsen PH, et al. In situ characterization of Nitrospira-like nitrite-oxidizing bacteria active in wastewater treatment plants. Appl. Environ. Microbiol. 2001;67:5273-5284.

[48] Wagner M, Rath G, Koops HP, et al. In situ analysis of nitrifying bacteria in sewage treatment plants. Water Sci. Technol. 1996;34:237-244. 
Table 1. Operational conditions of the semi-continuous photo-bioreactor during the experiments.

\begin{tabular}{cc|cccc}
\hline \multirow{2}{*}{ Experiment } & $\begin{array}{c}\text { Operational } \\
\text { days }\end{array}$ & $\begin{array}{c}\text { PBR light } \\
\text { intensity } \\
\left(\mu \mathrm{E} \cdot \mathrm{m}^{-2} \cdot \mathrm{s}^{-1}\right)\end{array}$ & $\begin{array}{c}\text { Temperature } \\
\left({ }^{\circ} \mathrm{C}\right)\end{array}$ & $\begin{array}{c}\text { Dissolved } \\
\text { oxygen } \\
(\% \text { saturation })\end{array}$ \\
\hline \multirow{3}{*}{ Light effect } & L1 & 17 & 40 & $22 \pm 1$ & $102 \pm 4 \%$ \\
& L2 & 29 & 85 & $22 \pm 1$ & $105 \pm 2 \%$ \\
& L3 & 34 & 125 & $22 \pm 1$ & $110 \pm 2 \%$ \\
\hline Temperature & T1 & 12 & 85 & $23 \pm 2$ & $108 \pm 6 \%$ \\
\hline
\end{tabular}


Table 2. Mean values \pm standard deviation on steady stage (Exp. L1, L2 and L3).

\begin{tabular}{|c|c|c|c|c|}
\hline Parameter & Units & Exp. L1 & Exp. L2 & Exp. L3 \\
\hline VSS & $\mathrm{mgVSS} \cdot \mathrm{L}^{-1}$ & $429 \pm 15$ & $658 \pm 35$ & $755 \pm 79$ \\
\hline Eukaryotic cells $\left(\times 10^{9}\right)$ & cells $\cdot \mathrm{L}^{-1}$ & $6.55 \pm 0.04$ & $11.90 \pm 1.59$ & $14.61 \pm 2.91$ \\
\hline N-load & $\mathrm{mg} \cdot \mathrm{d}^{-1}$ & $48.2 \pm 5.9$ & $56.2 \pm 8.4$ & $57.3 \pm 5.0$ \\
\hline P-load & $\mathrm{mg} \cdot \mathrm{d}^{-1}$ & $5.9 \pm 0.7$ & $6.8 \pm 0.7$ & $7.4 \pm 0.7$ \\
\hline $\mathrm{N}: \mathrm{P}$ ratio & molar & $13.3 \pm 0.7$ & $18.5 \pm 1.1$ & $17.6 \pm 1.7$ \\
\hline mARE & $\%$ & $73.9 \pm 2.9$ & $98.3 \pm 1.9$ & $99.3 \pm 0.4$ \\
\hline ARE & $\%$ & $97.2 \pm 2.3$ & $99.8 \pm 0.2$ & $99.9 \pm 0.2$ \\
\hline PRE & $\%$ & $98.6 \pm 1.4$ & $99.2 \pm 0.7$ & $99.5 \pm 0.2$ \\
\hline mARR & $\mathrm{mgN} \cdot \mathrm{L}^{-1} \cdot \mathrm{d}^{-1}$ & $3.47 \pm 0.95$ & $6.43 \pm 1.49$ & $6.92 \pm 1.05$ \\
\hline ARR & $\mathrm{mgN} \cdot \mathrm{L}^{-1} \cdot \mathrm{d}^{-1}$ & $5.28 \pm 0.93$ & $6.44 \pm 1.47$ & $6.96 \pm 1.03$ \\
\hline PRR & $\mathrm{mgP} \cdot \mathrm{L}^{-1} \cdot \mathrm{d}^{-1}$ & $0.61 \pm 0.14$ & $0.78 \pm 0.16$ & $0.90 \pm 0.16$ \\
\hline mARE/I & $\mathrm{mgN} \cdot$ molphoton $^{-1}$ & $88.1 \pm 24.2$ & $76.7 \pm 17.8$ & $59.0 \pm 8.9$ \\
\hline $\mathrm{ARE} / \mathrm{I}$ & $\mathrm{mgN} \cdot$ molphoton $^{-1}$ & $134.1 \pm 23.7$ & $76.8 \pm 17.6$ & $59.3 \pm 8.8$ \\
\hline PRE/I & $\mathrm{mgP} \cdot$ molphoton $^{-1}$ & $15.5 \pm 3.5$ & $9.3 \pm 1.9$ & $7.6 \pm 1.4$ \\
\hline Chlorophyll content & $\mathrm{mg} \cdot \mathrm{gVSS}^{-1}$ & $4.18 \pm 0.99$ & $2.44 \pm 0.69$ & $1.88 \pm 0.44$ \\
\hline Productivity & $\operatorname{mgVSS} \cdot \mathrm{L}^{-1} \cdot \mathrm{d}^{-1}$ & $50.5 \pm 9.6$ & $80.3 \pm 6.5$ & $94.3 \pm 7.9$ \\
\hline
\end{tabular}


a)

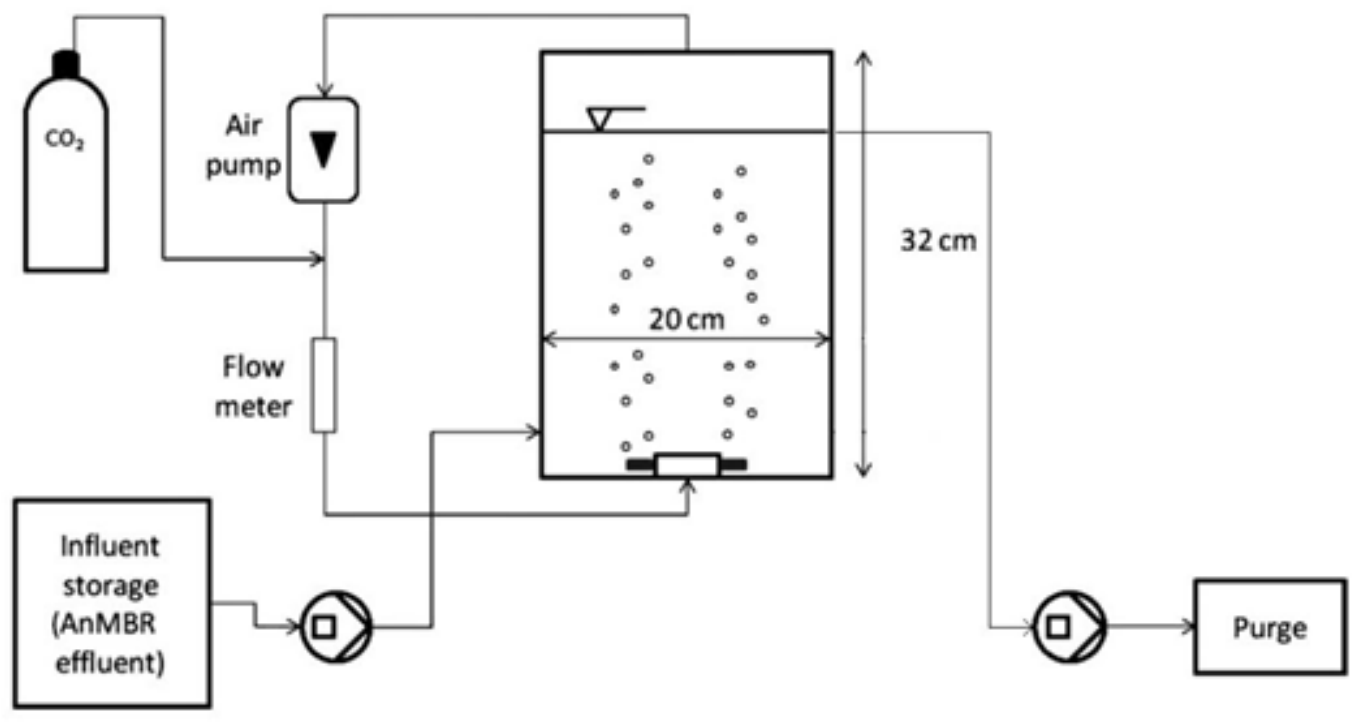

b)

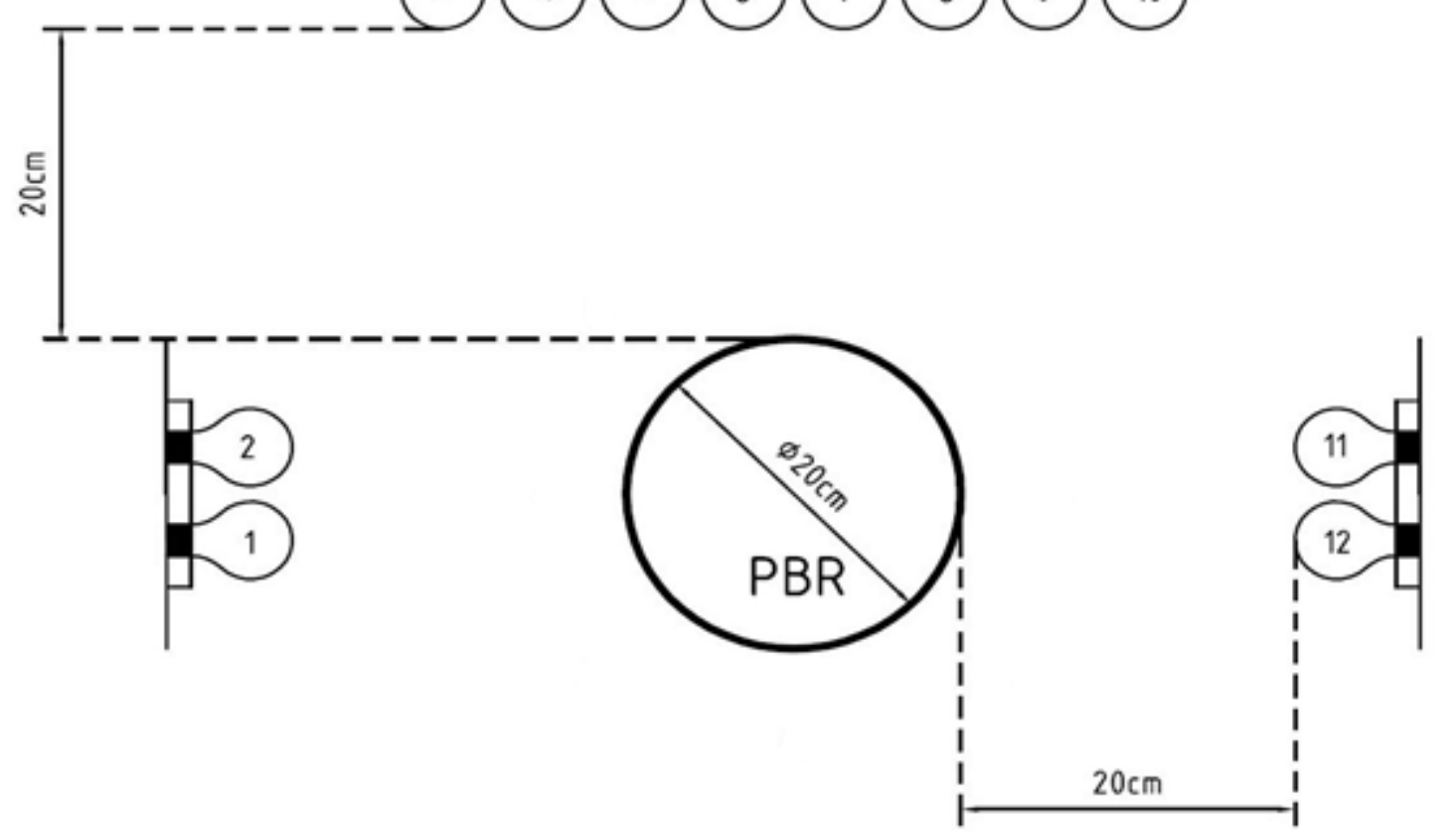

Figure 1. a) Lab-scale cylindrical photobioreactor [5]; and b) lamps distribution around the PBR. 


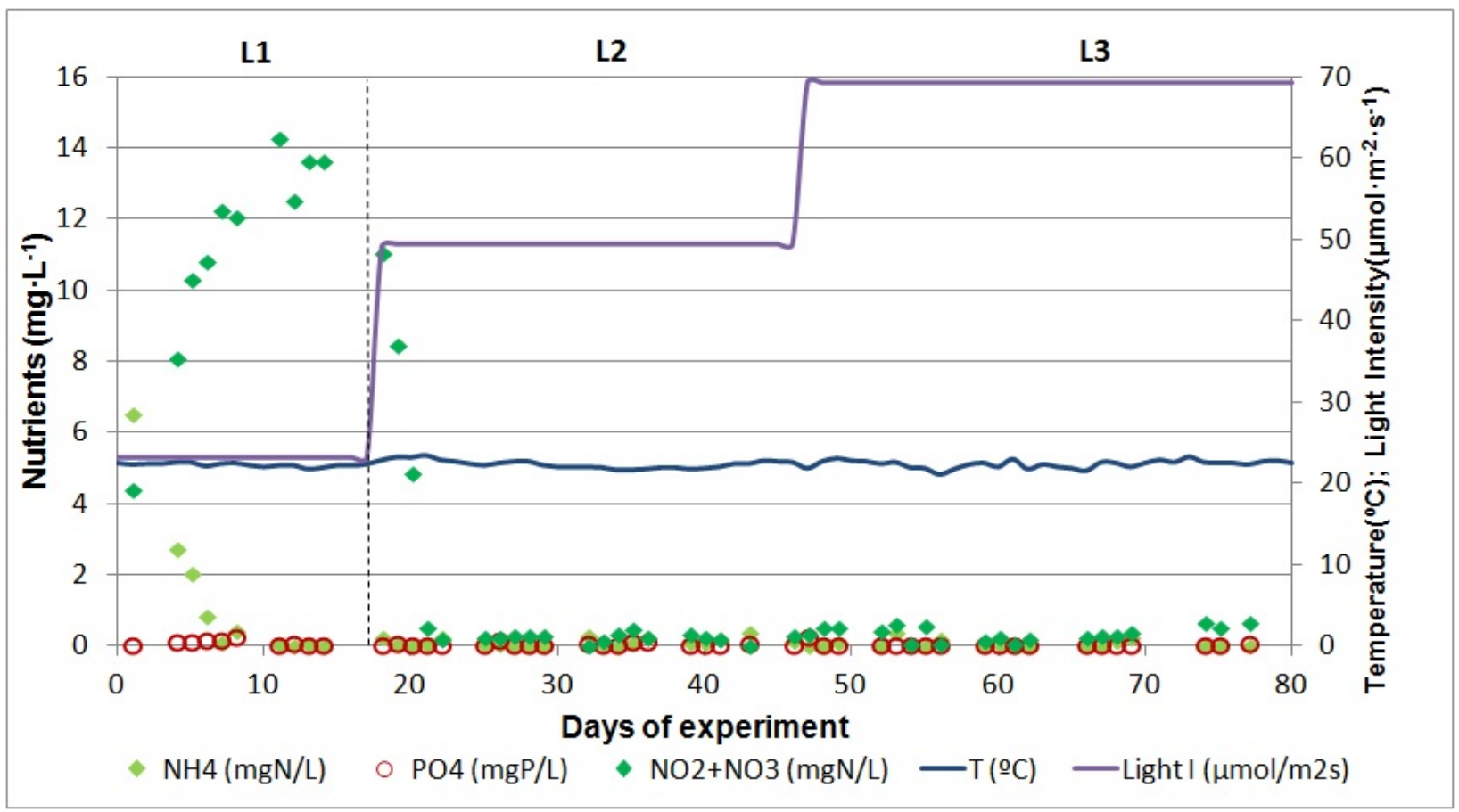

Figure 2. Evolution of nutrients concentration, temperature and light intensity in the PBR during Exp. L1, L2, and L3. 


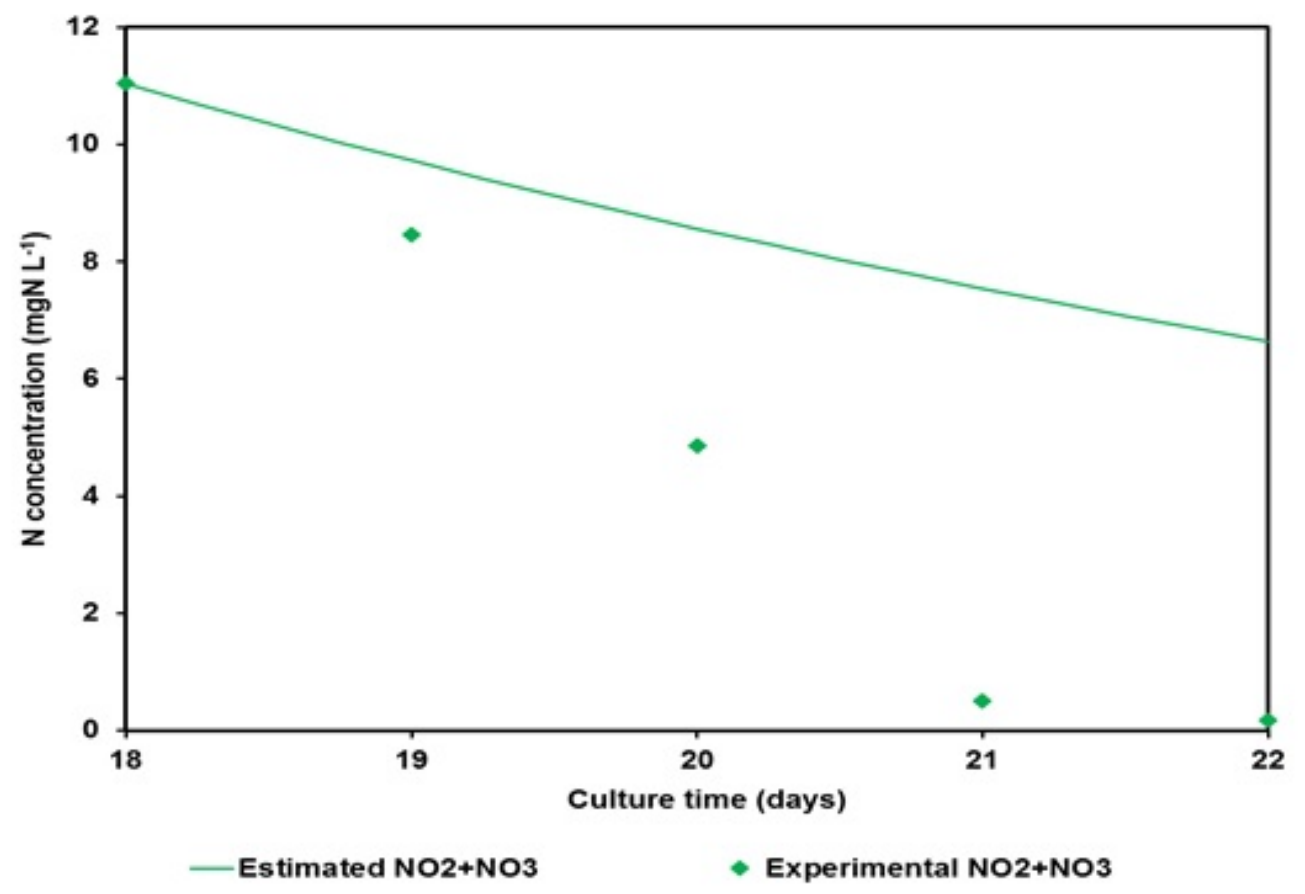

Figure 3. Nitrite and nitrate evolution during the first days of the Exp. L2: experimental results and theoretical washout calculated not considering nitrification. 
a)

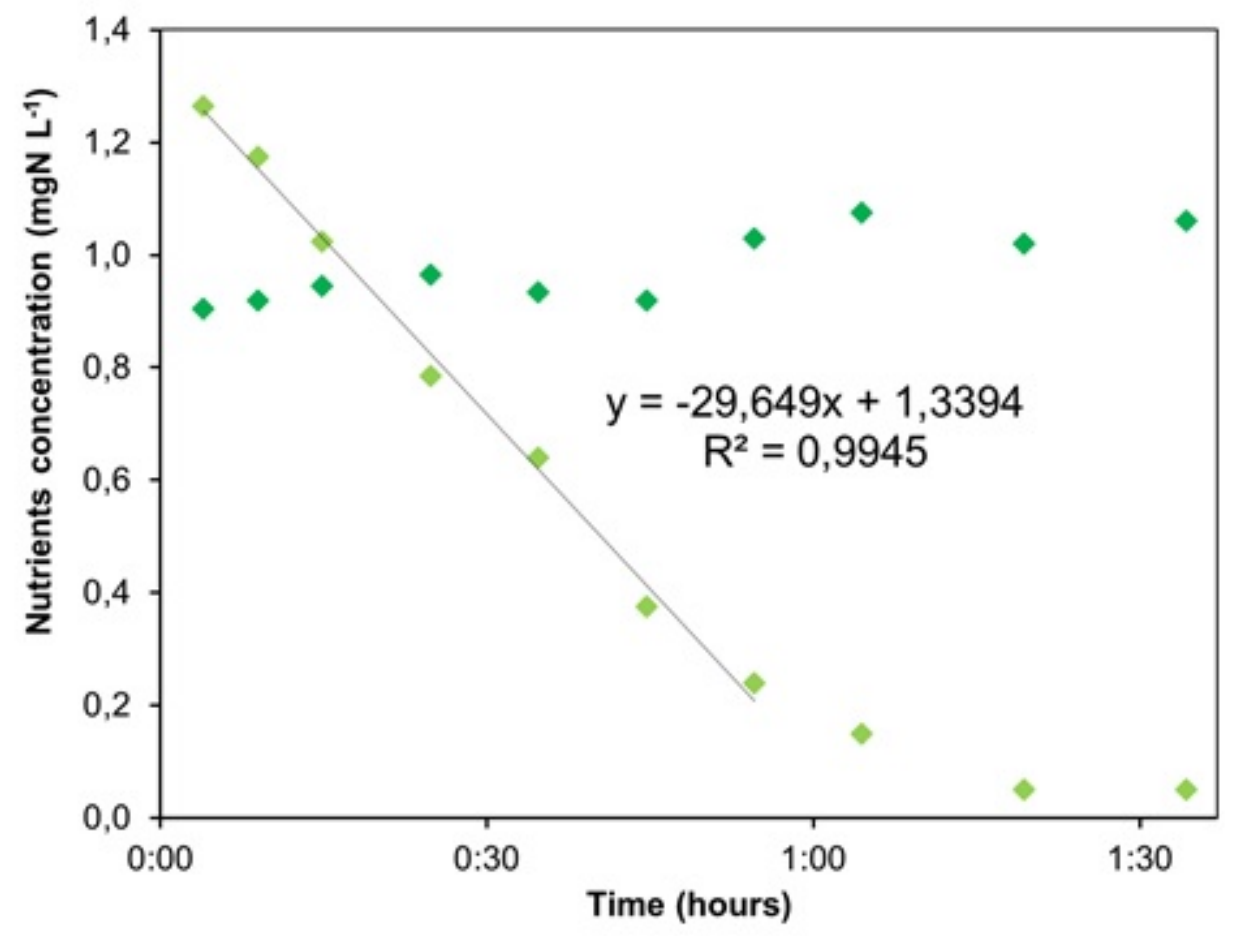

b)

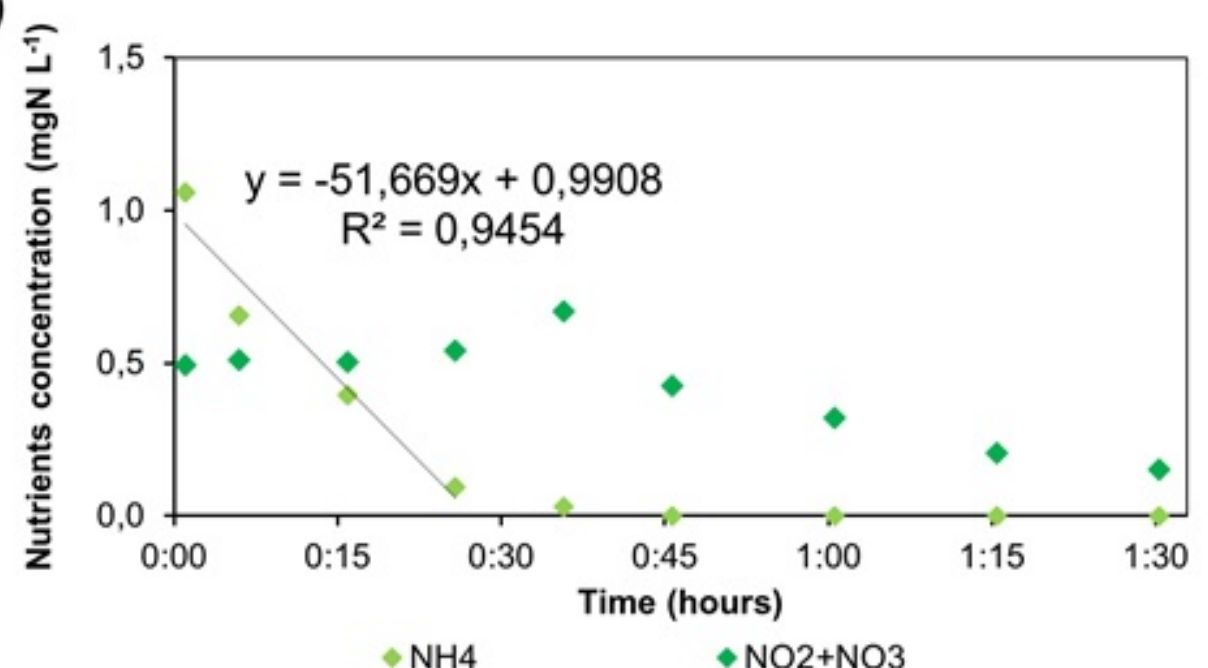

Figure 4. Nutrient removal rate monitoring during one cycle feed: a) in Exp. L2; and b) in Exp. L3. 


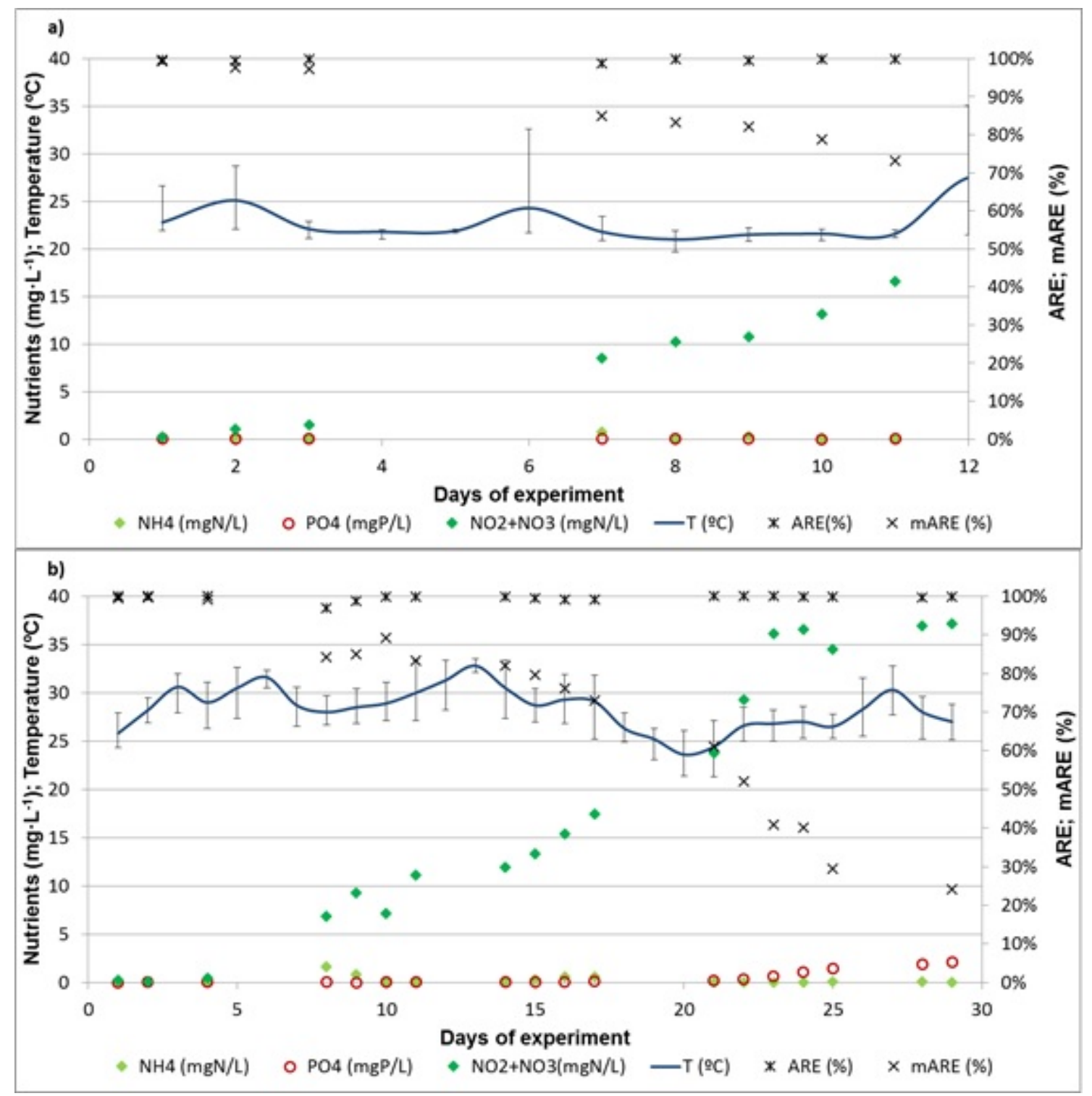

Figure 5. Evolution of nutrients concentration and temperature in the PBR: a) In Exp. $\mathrm{T} 1 ; \mathrm{b})$ in Exp. T2. 


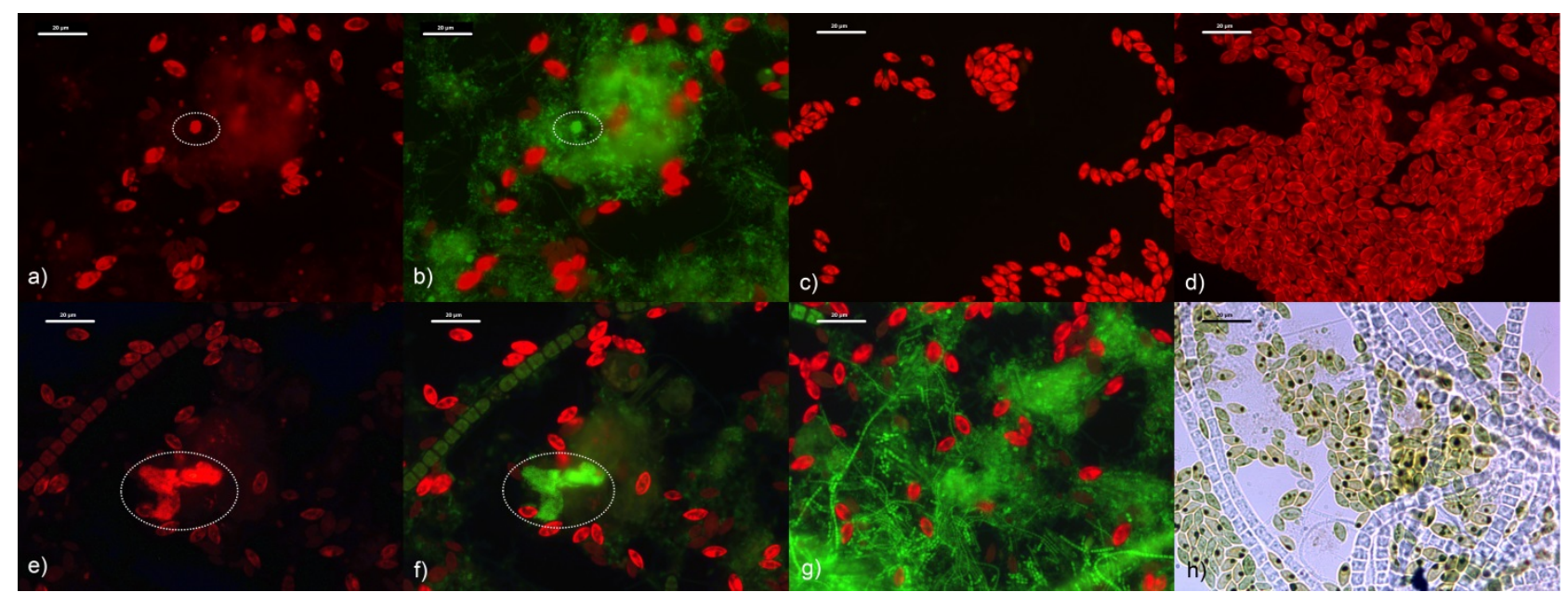

Figure 6. Samples observed under epifluorescence microscope (Leica DM2500/

DFC420c digital camera) using a 63x objective. Scale bar $=20 \mu \mathrm{m}$. (a, b) Exp. L1, the same fields of view are shown: a [hybridized with NSO1225 probe (red), a little group of AOB indicated by a white circle] and b [hybridized with EUBMIX probe (green)]; (c, d) Exp. L2, Scenedesmus spp. as dominant genus; (e, f) Exp. T1, the same fields of view are shown: e [hybridized with NSO1225 probe (red), a higher group of AOB indicated by a white circle] and f [hybridized with EUBMIX probe (green)]; (g) Exp. T2, sample hybridized with EUBMIX probe (green) allows to identify diverse groups of bacteria; (h) Exp. T2, bright-field image showing Scendesmus spp. and Cyanobacteria. 
Table A1. Oligonucleotide sequences employed in this study.

\begin{tabular}{lllllll}
\hline Probe & \multicolumn{2}{l}{ Sequence $\left(5^{\prime} \rightarrow 3^{\prime}\right)$} & & Specificity & $\begin{array}{l}\% \\
\text { FA }\end{array}$ & Ref. \\
\hline $\begin{array}{l}\text { EUB 338 } \\
\text { I }\end{array}$ & $\begin{array}{l}\text { GCT GCC } \\
\text { AGG AGT }\end{array}$ & TCC & CGT & Eubacteria & $0-50$ & {$[33]$} \\
\hline $\begin{array}{l}\text { EUB 338 } \\
\text { II }\end{array}$ & $\begin{array}{l}\text { GCA GCC } \\
\text { AGG TGT }\end{array}$ & ACC & CGT & Planctomycetes & $0-50$ & {$[45]$} \\
\hline $\begin{array}{lllllll}\text { EUB 338 } \\
\text { III }\end{array}$ & $\begin{array}{l}\text { GCT GCC } \\
\text { AGG TGT }\end{array}$ & ACC & CGT & Verrucomicrobiales & $0-50$ & {$[45]$} \\
\hline NSO1225 & $\begin{array}{l}\text { CGC CAT TGT ATT ACG } \\
\text { TGT GA }\end{array}$ & $\begin{array}{l}\text { Betaproteobacterial } \\
\text { ammonia-oxidizing } \\
\text { bacteria }\end{array}$ & 45 & {$[46]$} \\
\hline Ntspa712 & $\begin{array}{l}\text { CGC CTT CGC } \\
\text { CGG CCT TCC }\end{array}$ & CAC & $\begin{array}{l}\text { Most members of } \\
\text { the } \\
\text { Nitrospirae }\end{array}$ & phylum & 50 & {$[47]$} \\
\hline NIT 3 & $\begin{array}{l}\text { CCT GTG CTC CAT GCT } \\
\text { CCG }\end{array}$ & Nitrobacter spp & 40 & {$[48]$} \\
\hline
\end{tabular}




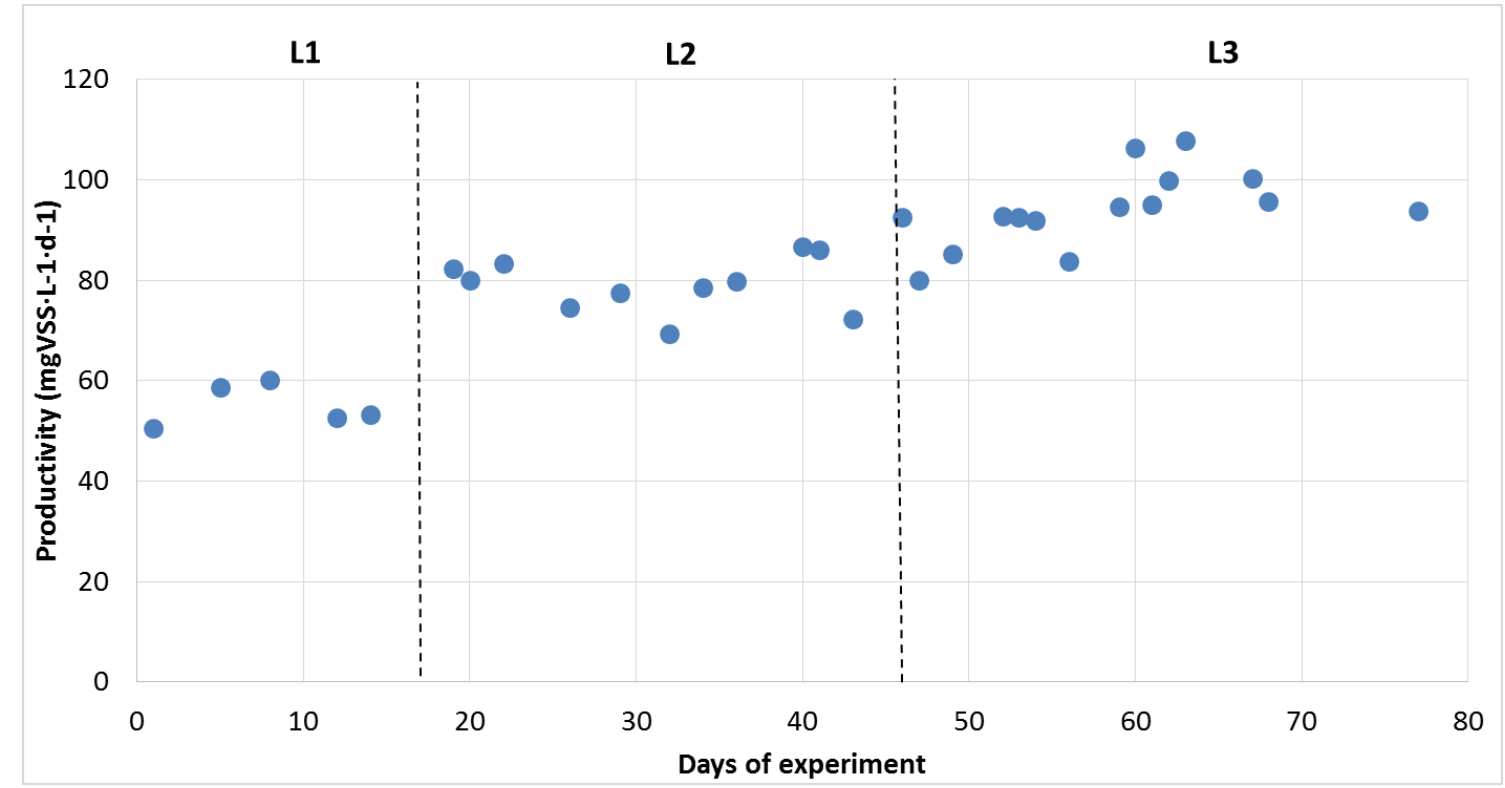

Figure A.1. Evolution of biomass productivity during Exp. L1, L2, and L3. 